\title{
Landscape Effects on Decomposition
}

\author{
Walter G. Whitford ${ }^{1}$, Yosef Steinberger ${ }^{2 *}$ \\ ${ }^{1}$ USDA-ARS Jornada Experimental Range, New Mexico State University, Las Cruces, NM, USA \\ ${ }^{2}$ Department of Biology, Bar-Ilan University, Ramat Gan, Israel \\ Email: *Yosef.Steinberger@biu.ac.il
}

How to cite this paper: Whitford, W.G. and Steinberger, Y. (2021) Landscape Effects on Decomposition. Open Journal of Ecology, 11, 267-275.

https://doi.org/10.4236/oje.2021.113019

Received: February 3, 2021

Accepted: March 2, 2021

Published: March 5, 2021

Copyright $\odot 2021$ by author(s) and Scientific Research Publishing Inc. This work is licensed under the Creative Commons Attribution International License (CC BY 4.0).

http://creativecommons.org/licenses/by/4.0/ (c) (i) Open Access

\begin{abstract}
The average annual rainfall was close to the average for the Jornada Experimental Range basin $\left(225 \mathrm{~mm} \cdot \mathrm{y}^{-1}\right)$. Decomposition of leaf litter bags on the soil surface was a function of the rainfall at the site and of soil texture. Sites with the highest splash erosion and infiltration (highest sand content) had the highest decomposition rates. There was no evidence that run-off, run-on processes had an effect on the decomposition of surface litter. Root decomposition was only different at one of the tarbush sites ( $p>0.001)$ and that difference was primarily due to soil texture and spatial distribution of rainfall. High concentration of the clay-silt fraction resulted in differences in mass loss of surface litter at grassland, dry-lakes, and tarbush sites. One site at each of these was different from the other two sites because they are between 8 and $20 \mathrm{~km}$ from the other two sites.
\end{abstract}

\section{Keywords}

Surface Litter Decomposition, Tethered Root Mass Loss, Rainfall, Splash Erosion

\section{Introduction}

In mesic environments, decomposition rates can be predicted by a regression model based on actual evapotranspiration (AET) and lignin content of the dead plant material [1]. The AET model greatly underestimates mass losses in deserts [2]. In a study of five species (one shrub, one tree, and three grass species) there were no consistent results relating mass losses to litter chemistry or antecedent precipitation [3]. Experiments using sprinkler irrigation to simulate rainfall found that litter placed in the field during an extended dry period lost mass faster than non-irrigated litter [4]. In the winter rainfall Negev Desert, irrigation increased mass losses during the rainless summer [5]. Imposition of drought had no effect on decomposition rates of creosote bush leaf litter on the soil surface. 
However, decomposition rates of roots of a perennial herb were reduced by imposing drought but with irrigation were the same as the control [6]. In a study of surface litter decomposition on a watershed, highest rates were recorded for a run-on area near the base of the watershed. The higher rate was attributed to sediment from run-off burying the litter bags [7]. The only report of decomposition on a watershed is that of Cepeda-Pizarro and Whitford (1990) [7].

Decomposition of roots is the major contributor to the recalcitrant soil organic carbon pool. Roots vary considerably in initial lignin content (approximately $17 \%$ for roots of an annual plant, $24 \%$ for roots of a woody shrub, and $27 \%-29 \%$ for roots of several grasses. Decomposition rates of roots were inversely related to the initial lignin content and also to the initial nitrogen content which were lower in the roots of grasses than in the other species examined [8]. Average annual mass losses from woody roots (40\%) were considerably lower than the average annual mass losses from roots of herbaceous annuals (85\% $90 \%$ ) which was related to the lignin content of the roots and to the susceptibility of herbaceous roots to attack by subterranean termites [9] [10]. A study that compared creosote bush (Larrea tridentata) and mesquite (Prosopis glandulosa) leaf litter and roots reported that leaf litter placed on the soil surface had higher mass loss than the roots of these woody shrubs [11]. Drought was imposed by the use of "rain-out" shelters. In both species, leaf litter decayed at a faster rate and was less affected by drought than the decay of roots [11]. Differences in the chemical structure of roots of woody plants and annual plants plus soil texture accounted for the differences between leaf litter decomposition and the decomposition of roots.

A study of the decomposition of fine ( $\leq 2 \mathrm{~mm})$ and coarse roots of Artemesia halodendron reported initial rapid mass loss in the first 53 days (36.2\% of coarse roots and $39.8 \%$ of fine roots). After 381 days of the experiment, there were $18.4 \%$ of coarse roots and $30.5 \%$ of fine roots that were added to the initial mass loss [12]. Another study in a Chinese desert, reported that mass losses of roots were controlled by the initial lignin content and the lignin to nitrogen ratio but that water and nitrogen addition had no effect on root mass loss [13]. Imposed drought reduced decomposition rates of the roots by approximately $25 \%$ over the extent of the experiment [11].

No studies of root decomposition or surface litter decomposition have examined landscape-watershed relationships of decomposition rates to run-off, run-on processes. We hypothesized that run-off, run-on processes and differences in soil type would result in differences in decomposition rates [7]. Soil type is essential for precipitation infiltration and splash erosion. The amount and intensity of precipitation determine the quantity of run-off and run-on from sloping terrain. We expected that decomposition rates of surface litter would be lower than that decomposition of tethered roots.

\section{Site Descriptions}

We established three sites in each of five vegetation types that typify the Chihu- 
ahuan Desert: mesquite (Prosopis glandulosa) two in coppice dunes (md) and one on level soil (ml) (Table 1). The black-grama (Bouteloua eriopoda) grassland sites included one at base of a mountain (gm), one at the base of a watershed (gb), and one in a flat, black grama grassland (gIBP). For tarbush (Flourensia cernua) two sites were mid-slope separated by an elevated road bed (tw and te) and one near the lowest point on the watershed that was approximately 8 $\mathrm{km}$ from the other two sites (tn). There were three creosote bush sites (Larrea tridentata) on a sloping piedmont: one on shallow soil $15-30 \mathrm{~cm}$ from the surface to an indurated calcium carbonate layer $\left(\mathrm{C}_{\text {cali }}\right)$, a site with gravel surface soils $\left(\mathrm{C}_{\text {grav }}\right)$ and one site on deep sandy soil $\left(\mathrm{C}_{\text {sand }}\right)$. Two of the dry lake $\left(\mathrm{P}_{\text {small }}\right)$ and $\left(\mathrm{P}_{\text {coll }}\right)$ sites were dominated by Panicum obtusum. These sites flood during intense rains. One dry lake basin $(\mathrm{Pt})$ was dominated by tobosa grass (Pleuraphis mutica) that rarely floods. All plots were fenced with four strand barbed wire fence to prevent cattle from disturbing the experiment.

Two of the grassland sites are on the same watershed with one site at the base of a mountain and the other on the low slopes of the watershed and the third site is on shallow soils with a caliche (calcium carbonate) layer at a depth of $15-30$ $\mathrm{cm}$. This site is approximately $20 \mathrm{~km}$ north of the other grassland sites. The smallest playa (Ps) (dry lake) has a diameter of around $200 \mathrm{~m}$ and a total area of approximately 5 hectares. The other playa (Pc) is a 40 hectare dry-lake at the base of a watershed. The soil at the dry lake bed dominated by tobosa grass (Pleuraphis mutica) has different soils and is located more than $20 \mathrm{~km}$ from any of the other sites. It is a large dry lake (playa diameter $>1 \mathrm{~km}$ ). That dry lake

Table 1. Soil analysis of all of the sites used in the decomposition-landscape study.

\begin{tabular}{cccc}
\hline Clay (\%) & Silt (\%) & Sand (\%) & Dominant Vegetation \\
\hline 8.2 & 6.2 & 86 & Md dune \\
9.9 & 6.7 & 82 & Md-dune \\
11 & 6.8 & 82 & Ml-level \\
11 & 26 & 55 & Te-east \\
21 & 24 & 55 & Tw-west \\
17 & 22 & 59 & Tn-north \\
8.9 & 9.1 & 82 & Gb-basin \\
26 & 19 & 55 & Gs-Mnt \\
6 & 13 & 81 & Gi-distant \\
72 & 27 & 1 & Ps-small \\
57 & 33 & 2 & Pc-college \\
36 & 30 & 33 & Pt-tobosa \\
9 & 18 & 72 & Cc-caliche \\
13 & 19 & 68 & Cg-gravel \\
13 & 15 & 72 & Cs-sand \\
\hline & & & \\
\hline 3 & 30 & 53 & 5 \\
\hline
\end{tabular}


(with tobosa grass ( $P$. mutica) has different precipitation from the other two playa sites and receives little or no run-on. Several sites were located on a watershed from the base of a mountain (gm) with creosote bush sites on the upper piedmont slopes and one grassland site $(\mathrm{gb})$ that terminated in a dry lakebed $\left(\mathrm{P}_{\text {coll }}\right)$.

\section{Methods}

Air-dried to a constant weight, five grams of creosote bush leaf litter was confined in fiberglass screen (1.5 mm mesh) litter bags. We placed 10 litter bags at the base of shrubs or grass tussocks in each plot. Bags were placed in $1 \mathrm{~m}^{2}$ plots that were selected at random from the 50 , one $\mathrm{m}^{2}$ plots. Litter bags were placed in the field in January and collected at the end of one year.

D. wislizenii roots were cleaned and air dried to a constant mass prior to attaching a metal tag with a wire to a root. The roots were placed in the field at the end of May before the monsoon rain season. When we went to collect roots at the end of three months, there was evidence of roots being pulled up by the tag. We found several tags in nearby pack rat mounds (Neotoma spp.). We only collected three samples in the early September sample and when we went back to collect the 6 month samples, most of the tags were gone and we were left with few root samples. Therefore, the root decomposition is for 3 months buried in the soil and we were unable to access large samples for statistical analysis. The data are for a variable number of roots that were not removed by animals. All data were analyzed by an analysis of variance with significant differences at the $\mathrm{p}$ $<0.05$ level.

We collected soil cores to a depth of $>30 \mathrm{~cm}$ at each site in order to obtain quantitative data on soil textures. We used the hydrometer method for soil texture as described by Gee and Bauder (1979) [14]. We did not have rain gauges at each of the 15 sites and used the rainfall at the mid-slope of a watershed for the dry lake at the base of the watershed, two of the grassland sites, and all of the creosote bush sites. Two of the mesquite sites were coppice dunes that formed around the shrub and one mesquite site was a sandy site with little topography.

\section{Results}

Creosote bush leaf litter decomposition on the surface of the soil was more a function of rainfall at the site than run-off, run-on relationships. For example, there were no differences in decomposition under mesquite shrubs $(61.3 \%$ mass remaining) with an annual rainfall of $161.8 \mathrm{~mm}$ (Table 2). There were no differences at two of the tarbush sites that received $152.7 \mathrm{~mm}$ of precipitation. The other tarbush site received $261.7 \mathrm{~mm}$ of precipitation and had higher mass loss (65\%) than the other two F. cernua sites with an average mass loss of $34 \%$ (Figure 1). The grassland sites were also primarily affected by annual rainfall: mountain grassland mass loss $78 \%$ with precipitation of $265.7 \mathrm{~mm}$, basin grassland mass loss $43 \%$ with precipitation of $93.7 \mathrm{~mm}$, and distant grassland $64 \%$ 


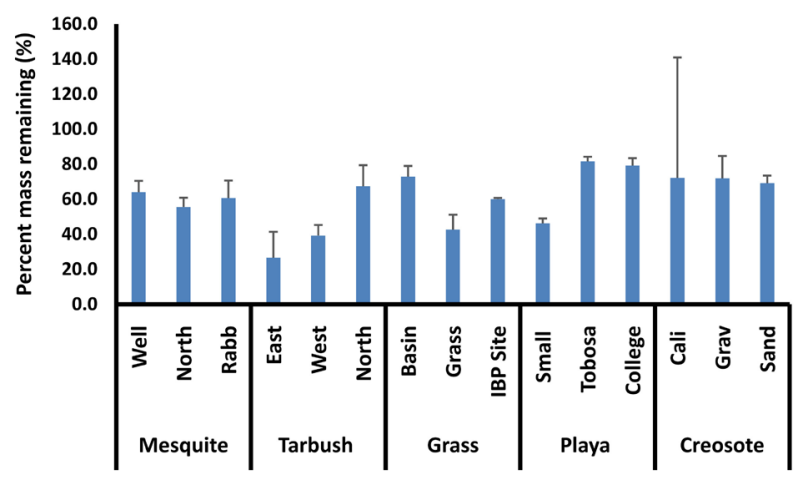

Figure 1. Litter remaining in litter bags with air-dried creosote bush (Larrea tridentata) leaves and small stems.

Table 2. Means and standard deviations of mass remaining (percent of original mass) of tagged roots in each of the major vegetation types within the Chihuahuan Desert.

\begin{tabular}{ccc}
\hline Vegetation Type & mean & std dev \\
\hline Prosopis glandulosa & 0.60 & \pm 0.07 \\
Bouteloua eriopoda & 0.58 & \pm 0.14 \\
Larrea tridentata & 0.71 & \pm 0.08 \\
Flourensia cernua & 0.41 & \pm 0.20 \\
Playa Dry Lake & 0.70 & \pm 0.17 \\
\hline
\end{tabular}

mass remaining with a precipitation of $112.9 \mathrm{~mm}$. Two of the dry lake sites that flooded had high decomposition rates of more than $80 \%$ with precipitation of $200.8 \mathrm{~mm}$ and the litter mass remaining at the tobosa grass dry lake was $46 \%$. Precipitation at this site was $200 \mathrm{~mm}$. The creosote bush sites with precipitation of $204.7 \mathrm{~mm}$ reported an average mass loss of $72 \%$. None of the creosote bush sites were different from each other because of the large variance (Figure 1).

The differences in mass loss percentage among the roots that were in the field for three months and roots collected after 6 months were very small. At most of the sites, percent mass remaining was between $60 \%$ and $80 \%$ with the lowest values recorded at the grassland site at the base of a mountain (42\%) and the small dry-lake (46\%) (Figure 1). Two of the tarbush sites had low percent of mass loss while the one site had a high percent mass loss after three months in the field (Figure 1). That site has a different soil type than the other two F. cernua sites. At the high decomposition tarbush site, the texture measurements were: $11 \%$ clay, $26.4 \%$ silt, and sand $62.6 \%$. The average texture of the other sites was: clay $-16.5 \%$, silt $-25 \%$ and sand $-55 \%$. The precipitation at this site was $261 \mathrm{~mm}$ and at the other tarbush sites was $152.7 \mathrm{~mm}$. The higher sand content and high precipitation this site allowed for greater infiltration and splash erosion of rainfall because of the higher sand content. The lower precipitation and higher clay-silt fraction of the soil (47.3\%) compared with the clay-silt fraction of $52.5 \%$ of the other two tarbush sites also contributed to the differences in root decomposition at the site. 
The highest percent mass loss from the roots was at two of the dry-lakes where the surface soils were cracking clays that seal when the dry-lake was flooded. The rainfall at the dry lakes dominated by Panicum obtusum was 132 $\mathrm{mm}$ while the tobosa grass playa received $165.9 \mathrm{~mm}$ of rainfall. The tobosa grass dry lake was much larger ( $>1 \mathrm{~km}$ in diameter) than the dry lakes with Panicum obtusum as the dominant grass on the lake bed. The soil at the tobosa grass dry lake had a lower clay content $46 \%$ vs. $54.6 \%$ than the other dry lakes, higher bulk density (1.6 vs. 1.4$)$ and a much higher sand content ( $26.4 \%$ vs. $7.7 \%)$. Splash erosion detaches soil which can cover leaf litter and accelerate of decomposition. Factors that affect detachability of soil materials include: bulk density, soil texture, and soil structure [15]. Sandy soils have the highest probability of splash erosion and cracking clays the lowest probability.

The only vegetation assemblages where decomposition of roots was significantly different was the tarbush site at the lowest elevation and most distant from the other two sites. Most convectional storms in the Chihuahuan Desert are less than $2 \mathrm{~km}$ in diameter which explains the difference in precipitation of the two sites and the more distant tarbush site [6]. The soils at the mesquite sites are sandy soils with high infiltration rates $(83.3 \%$ sand). The mesquite sites are more than $20 \mathrm{~km}$ from most of the other sites. All of the creosote bush sites had similar rates of mass loss (Figure 1) and these sites are all on erosion slopes dominated by $L$. tridentata with sand contributing the largest fraction of the soil (59\% - 72\%).

\section{Discussion}

Decomposition rates of creosote bush leaf litter were primarily due to soil differences and spatial variation in precipitation. The one tarbush site that was different from the other two was a site that had the lowest clay content relatively high sand content. Since the site with the highest decomposition rate had an annual precipitation of $261.7 \mathrm{~mm}$ and the other two tarbush sites had a precipitation total for the year of $152.7 \mathrm{~mm}$, the differences in decomposition rates are probably due to precipitation differences. The major difference in the tarbush sites was the precipitation not soil differences. The difference between the two sites with the same rainfall was attributed to the elevated road bed that blocked run-off water from the site with the lowest decomposition rate. In two of the three grassland sites, precipitation differences account for some of the variation among sites (265.7 $\mathrm{mm}$ at the base of a mountain and $220 \mathrm{~mm}$ for the low elevation site). However the grassland site that was not on the watershed and was more than $20 \mathrm{~km}$ from the watershed sites had different soils (45\% clay-silt fraction) and only 55\% sand with $220 \mathrm{~mm}$ annual precipitation. The other grassland sites had clay-silt fractions of $14 \%$ and sand fractions $>80 \%$. There was an absence of intense, large convectional storms that supplied rainfall sufficient to cause run-off during the year of the study. The two dry lakes near the mountains received at least one sufficiently large precipitation event to produce standing 
water on the lake bottoms. The high decomposition rates for these two lakes are due to standing water. In a study that examined decomposition along a rainfall gradient in Israel, we found that decomposition of litter in mesh bags decayed at a rate commensurate with the rainfall of the areas [16]. In this study, rainfall and soil texture which affects water infiltration was involved in decomposition rate differences. Another factor that may accelerate the decomposition of surface litter is splash erosion. Splash erosion detaches soil which can cover leaf litter and accelerate decomposition. Factors that affect detachability of soil materials include: bulk density, soil texture, and soil structure [15]. Sandy soils have the highest probability of splash erosion and cracking clays the lowest probability. In a study that examined wind erosion and leaf litter decomposition in a mixed desert grassland [17] the accumulation of soil on leaf surfaces that form aggregates are likely to result from splash erosion. The kinetic energy of raindrops cause both sand and litter particles to be displaced [18].

The only vegetation assemblages where decomposition of roots was significantly different was the tarbush site at the lowest elevation and most distant from the other two sites. Decomposition rates of roots in the Chihuahuan Desert were equal to or higher than those reported for decomposing roots in mesic ecosystems [9]. Rates of decomposition of roots of woody shrubs and of herbaceous annuals were not affected by supplemental irrigation during a year with slightly above average annual precipitation. The absence of an irrigation effect was attributed to the relatively 'average' rainfall during the time that decomposition was measured. Average annual mass losses from woody roots (40\%) were considerably lower than the average annual mass losses from roots of herbaceous annuals $(85 \%-90 \%)$ which was related to the lignin content of the roots and to the susceptibility of herbaceous roots to attack by subterranean termites [9]. In a study that focused on the effects of termites on the decomposition of tethered roots, it was reported that decomposition rates of roots of annual plants was $62 \%$ mass loss with termites present and only $15 \%$ of mass lost on plots where termites had been chemically excluded [9]. However subterranean termites were found at all locations of the sites included in this study [19]. Termites may be responsible for the high decomposition rates of roots except for the dry lakes where there are no subterranean termites because of standing water on the clay soils.

Simulated drought reduced the mass loss from roots of an herbaceous perennial from an average mass loss of $80 \%$ to an average mass loss of 50\% [10]. Experimental studies using irrigation determined that supplemental rainfall by irrigation increased decomposition rates [20] [21]. In our study, the storm sizes and intensities did not result in run-off and run-on on the watershed where two of the grassland sites, all of the creosote bush sites, and one dry-lake site was located [22]. At these and other locations, soil characteristics determine water infiltration rates and splash erosion which drive decomposition rates in the absence of run-off. 


\section{Conclusion}

Creosote bush leaf litter decomposition was highest in two of the dry lakes that flooded from monsoon rains. Decomposition at the other sites was a function of the sand content of surface soils. Sand content enhances infiltration and splash erosion. Tethered roots were pulled up by animals (pack rats-Neotoma spp.) resulting in only three months of data.

\section{Acknowledgements}

We thank Harry Fowler, Wendy Wisdom, and J. H. Blizzard for assistance in setting up the experiment. This research was funded by the Long Term Ecological Research Program.

\section{Conflicts of Interest}

The authors declare no conflicts of interest regarding the publication of this paper.

\section{References}

[1] Meentmeyer, V. (1978) Macroclimate and Lignin Control of Decomposition Rates. Ecology, 59, 465-472. https://doi.org/10.2307/1936576

[2] Whitford, W.G., Meentemeyer, V., Seastedt, T.R., Cromack Jr., K., Crossley Jr., D.A., Santos, P., Todd, R.L. and Waide, J.B. (1978) Exceptions to the AET Model: Deserts and Clear-Cut Forest. Ecology, 62, 275-277. https://doi.org/10.2307/1936687

[3] Vanderbilt, K.L., White, C.S. and Hopkins, O. (2008) Above-Ground Decomposition in Arid Environments: Results of a Long-Term Study in Central New Mexico. Journal of Arid Environments, 72, 696-709. https://doi.org/10.1016/j.jaridenv.2007.10.010

[4] Whitford, W.G., Steinberger, Y., MacKay, W., Parker, L.W., Freckman, D., Wallwork, J.A. and Weems, D. (1986) Rainfall and Decomposition in the Chihuahuan Desert. Oecologia, 68, 512-515. https://doi.org/10.1007/BF00378764

[5] Steinberger, Y. and Whitford, W.G. (1988) Decomposition Process in the Negev Ecosystem. Oecologia, 75, 61-66. https://doi.org/10.1007/BF00378814

[6] Whitford, W.G. and Duval, D. (2019) Ecology of Desert Systems. 2nd Edition, Elsevier Publishing, Academic Press, Oxford.

[7] Cepeda-Pizzaro, J.G. and Whitford, W.G. (1990) Decomposition Patterns of Surface Leaf Litter of Six Plant Species along a Chihuahuan Desert Watershed. The American Midland Naturalist, 123, 319-330. https://doi.org/10.2307/2426560

[8] Mun, H.T. and Whitford, W.G. (1998) Changes in Mass and Chemistry of Plant Roots during Long-Term Decomposition on a Chihuahuan Desert Watershed. Biology and Fertility of Soils, 26, 16-22. https://doi.org/10.1007/s003740050336

[9] Whitford, W.G., Stinnett, K. and Anderson, J. (1988) Decomposition of Roots in a Chihuahuan Desert Ecosystem. Oecologia (Berlin), 75, 8-11. https://doi.org/10.1007/BF00378807

[10] Whitford, W.G. and Herrick, J.E. (1995) Maintaining Soil Processes for Plant Productivity and Community Dynamics. US EPA Environmental Monitoring Systems Laboratory. 
[11] Kemp, P.R., Reynolds, J.F., Virginia, R.A. and Whitford, W.G. (2003) Decomposition of Leaf and Root Litter of Chihuahuan Desert Shrubs: Effects of Three Years of Summer Drought. Journal of Arid Environments, 53, 21-39. https://doi.org/10.1006/jare.2002.1025

[12] Luo, Y., Zhao, X., Li, Y., Zuo, X., Lian, J. and Wang, T. (2016) Root Decomposition of Artemesia halodendron and Its Effect on Soil Nitrogen and Soil Organic Carbon in the Horquin Sandy Land, Northeastern China. Ecological Research, 31, 535-545. https://doi.org/10.1007/s11284-016-1362-y

[13] Zhao, H., Huang, G., Li, Y., Ma, J., Sheng, J., Jia, H. and Li, C. (2015) Effects of Increased Summer Precipitation and Nitrogen Addition on Root Decomposition in a Temperate Desert. PLoS ONE, 10, e0142380.

https://doi.org/10.1371/journal.pone.0142380

[14] Gee, G.W. and Bauder, J.W. (1979) Particle Size Analysis by Hydrometer: A Simplified Method for Routine Textural Analysis and a Sensitivity Test of Measure Parameters. Soil Science Society of America Journal, 43, 1004-1007. https://doi.org/10.2136/sssaj1979.03615995004300050038x

[15] Poesen, J. and Savat, J. (1981) Detachment and Transportation of Loose Sediments by Raindrop Splash. Part II. Detachability and Transportability Measurements. Catena, 8, 19-41. https://doi.org/10.1016/S0341-8162(81)80002-1

[16] Steinberger, Y., Shmida, A. and Whitford, W.G. (1990) Decomposition along a Rainfall Gradient in the Judean Desert, Israel. Oecologia, 82, 322-324. https://doi.org/10.1007/BF00317478

[17] Hewins, D.B., Sinsabaugh, R.L., Archer, S.L. and Throop, H.L. (2017) Soil Litter Mixing and Microbial Activity Mediates Decomposition and Aggregate Formation in a Shrub-Invaded Chihuahuan Desert Grassland. Plant Ecology, 218, 459-474. https://doi.org/10.1007/s11258-017-0703-4

[18] Dunkerley, D. and Geddes, N. (1999) The Influence of Organic Litter on the Erosive Effects of Raindrops Released from Desert Plants. Catena, 36, 303-313. https://doi.org/10.1016/S0341-8162(99)00050-8

[19] Nash, M.H., Anderson, J. and Whitford, W.G. (1999) Spatial and Temporal Variability in Foraging Intensities of Subterranean Termites in Desertified and Relatively Intact Chihuahuan Desert Ecosystem. Applied Soil Ecology, 12, 149-157. https://doi.org/10.1016/S0929-1393(98)00164-4

[20] Whitford, W.G. (1986) Decomposition and Nutrient Cycling in Deserts. In: Whitford, W.G., Ed., Pattern and Process in Desert Ecosystems, University of New Mexico Press, Albuquerque, 39-59.

[21] Whitford, W.G. (1996) Maintaining Soil Processes for Plant Productivity and Community Dynamics. In: West, N.E., Ed., Proceedings of the Fifth International Rangeland Congress: Rangelands in a Sustainable Biosphere, Society for Range Management, Denver, 33-37.

[22] Schaefer, D., Steinberger, Y. and Whitford, W.G. (1985) The Failure of Nitrogen and Lignin Control of Decomposition in a North American Desert. Oecologia, 65, 382-386. https://doi.org/10.1007/BF00378913 